\title{
Bulletin of the
}

Wolfgang Kalkreuth, Claus Andreasen, Henrik I. Petersen \& Lars Stemmerik: The petrology and provenance of coal artifacts from Thule settlements

in north-eastern Greenland

\section{Geological}

Jan Audun Rasmussen \& Finn Surlyk:

Rare finds of the coiled cephalopod Discoceras from the Upper Ordovician

of Bornholm, Denmark

Tod E. Waight, Dirk Frei \& Michael Storey:

Geochronological constraints on granitic magmatism, deformation,

cooling and uplift on Bornholm, Denmark

Bodil Wesenberg Lauridsen, Morten Bjerager \& Finn Surlyk:

The middle Danian Faxe Formation - new lithostratigraphic unit and a rare

taphonomic window into the Danian of Denmark

Tillie M. Madsen \& Jan A. Piotrowski:

Genesis of the glaciotectonic thrust-fault complex at Halk Hoved

southern Denmark
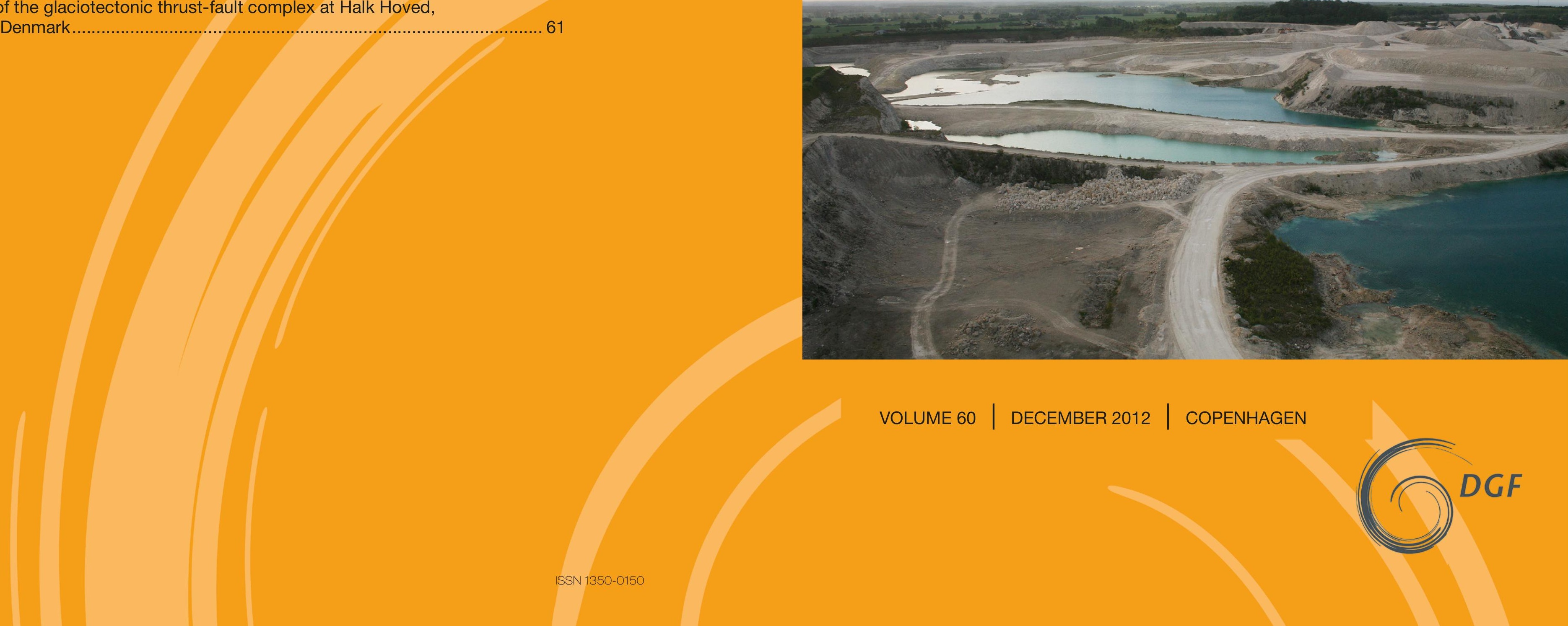

VOLUME 60 | DECEMBER 2012 | COPENHAGEN 
Chief editor

Lotte Melchior Larsen, Geological Survey of Denmark and Greenland (GEUS), Øster Voldgade 10, DK-1350 Copenhagen K, Denmark.

E-mail: lml@geus.dk

Scientific editors

Lars B. Clemmensen, Department of Geography and Geology, University of Copenhagen, Øster Voldgade 10, DK-1350 Copenhagen K, Denmark.

(clastic sedimentology, sedimentary basins and palaeoclimatology)

Ole Graversen, Department of Geography and Geology, University of Copenhagen, Øster Voldgade 10, DK-1350 Copenhagen K, Denmark. Tel: +45 3532 2447; E-mail: oleg@geo.ku.dk (structural geology and tectonics)

Michael Houmark-Nielsen, Natural History Museum of Denmark, University of Copenhagen, Øster Voldgade 5-7, DK-1350 Copenhagen K, Denmark Tel: +45 3532 4344; E-mail: michaelhn@snm.ku.d (Quaternary geology)

Jesper Milàn, Geomuseum Faxe, Østsjællands Museum, Østervej 2, DK-4640 Faxe, Denmark. (palaeontology)

Lars Nielsen, Department of Geography and Geology, University of Copenhagen, Øster Voldgade 10, DK-1350 Copenhagen K, Denmark.
Tel: +45 3532 2454; E-mail: In@geo.ku.dk (geophysics)

Erik Thomsen, Department of Geoscience, University of Aarhus, Høegh-Guldbergs Gade 2, DK-8000 Aarhus C, Denmark. Tel: +45 8942 2627; E-mail: erik.thomsen@geo.au.dk (palaeontology and stratigraphy)

Henrik Tirsgaard, Mærsk Olie og Gas AS, Esplanade 50, DK-1263 Copenhagen K, Denmark. Tel: +4561209140

E-mail: Henrik.tirsgaard@maerskoil.com (carbonate sedimentology, petroleum geology and sedimentary basins)
J. Richard Wilson, Department of Geoscience, University of Aarhus, Høegh-Guldbergs Gade 2,

(igneous petrology and geochemistry) The Bulletin publishes contributions of international
interest in all fields of geological sciences, with a natural emphasis on results of new work on material from Denmark, the Faroes and Greenland. Contributions based on foreign material may also be submitted to the Bulletin in cases where the author is a member of the Society. The rate of publishing is one volume per year. All articles are published as pdf-files immediately after acceptance and technical production. A paper editio of each volume is issued at the end of the year and is circulated to libraries only.

Scientific editing and reviewing is done on unpaid collegial basis and technical production expenses are covered by the membership fees.

The bulletin is freely accessible on the web page of the Geological Society of Denmark:

http://2dgf.dk/ publikationer/bulletin/index.html.

Instructions to authors:

See inside the back cover and also:

http://2dgf.dk/publikationer/bulletin/vejledning.html

Cover: The Faxe limestone quarry is a famous fossil-hunter locality which over the years has yielded thousands of wel-
preserved fossils from the coral and bryozoan mound complexes exposed there. Faxe has now given name to a new geological formation, the Faxe Formation (see this volume pp 47-60: Lauridsen, B.W., Bjerager, M. \& Surlyk, F: The middle Danian Fax window into the Danian of Denmark). A particular foph the mounds is described as the Baunekule faces which prith exceptionally well-preserved fossils. However, the localities with the Baunekule facies have now all been quarried away. The picture shows the quarry in 2012, viewed from NW; the locality called 'Ravns næse', shown on p 50 in a photo from 1908, was located approxinately between the two phestone heaps in the right background, and the locality 'Stationsvej' was situated Photo: Jesper Milàn, Geomuseum Faxe.

\section{Instructions to authors}

The Bulletin publishes articles normally not exceeding 16 printed pages, notes not longer than 4 pages, and short con-
tributions of maximum 1 printed page Longer articles may be tributions of maximum 1 printed page. Longer articles may be
published at the discretion of the editor, but it is advisable to published at the discretion of the editor, but it is advisable to
consult the editor before submitting long manuscripts. Short consult the editor before submitting long manuscripts. Short cles, presentation of current scientific activities, short scientific notes, or book reviews.

Manuscripts with complete sets of illustrations, tables, captions, etc., should be submitted electronically to the chief editor $(\operatorname{lml} \Subset$ geus.dk). The main text with references and figure captions either pdf, jpeg, or tiff format, and tables should be in Word text format, i.e. written in lines with tab spacing between table columns. "Word tables" are discouraged because they are not re-formatted easily. Consult the editor before submitting other formats.

Manuscripts will be reviewed by two referees; suggestions of referees are welcome. Articles will be published approximately in the order in which they are accepted for publication. The final cation rests with the chief editoript will be accepted for the scientific editors.

Manuscript

Language - Manuscripts should be in English. Authors who are not proficient in English should ask an English-speaking colleague for assistance before submission of the manuscript.
. Titte - Titles should be short and concise, with emphasis on words useful for indexing and information retrieval. An
abbreviated title to be used as running head must also be abbreviated

Abstract - An abstract in English must accompany all papers. It should be short (no longer than 250 words) factual and stress new information and conclusions rather than describing the contents of the manuscript. Conclude the abstract

with a list of key words.
Main text - Use 1.5 or double spacing throughout, and leave wide margins. Italics should be used only in generic and al., ibid., op. cit).

Spelling - Geological units named after localities in Greenland, formal lithostratigraphical units and intrusions named after
localities in Greenland remain unchanged even if the eponylocalities in Greenland remain unchanged even if the epony-
mous locality names have since been changed in accordance mous locality names have since been changed in accordance
with modern Greenlandic orthography. with modern Greenlandic or hography.
References to figures, tables and papers - References to figures and tables in the text should have the form: Fig. 1, Figs 1-3, Table 3 or as (Smith 1969, fig. 3) when the reference is to a figure in a cited paper.

References to papers are given in the form Smith (1969) or (Smith 1969). Combined citations by different authors are separated by a sentcolon, two or more papers by same auh hor(s) are cally and then alphabetically. Use 'et al' for three or more authors, e.g. Smith et al. (1985)
Reference list

Use the following style

go the Bulbjerg Formation. Bulletin ociety of Denmark 38, 119-144. [Note th is given in full].

mith, A.A., Jensen, B.B. \& MacStuff, C.C. 1987: Sandstones of Denmark, 2nd edition, 533 pp. New York: Springer Verlag. [For more than 10 authors, use first author followed by et al. mith, A.A., Jensen, B.B. \& MacStuff, C.C. 1992: CharacterizaCeology of Creenland. Ceological Survey of Detm (eds): Greenland Bulletin 40,1397-1438. [More than three editors - therefore et al. form is used.

Sorting - Danish letters $æ, \varnothing$ and å (aa) are treated as ae, o an a (aa), respectively.

1: Alphabetically by the first author's surname

2: Papers by one author: two or more papers are arranged chronologically

Papers by two authors: alphabetically after second author's name. Twoor more papers by the saly aftwo seythor

logically.
4: Papers by three or more authors: chronologically. Papers from the same year are arranged alphabetically after second, third, etc.author's name.

Authors themselves are responsible for the accuracy and completeness of their references. If incorrect references are found, the manuscript will be returned to the au hor for complete recheckcited in the paper (including figures, tables etc).

\section{Illustrations}

May be prepared in either black and white or colour. There is no colour charge. Horizontal illustrations are much to be preferred. Size of smallest letters in illustrations should net

All figures (including photographs) should be submitted in the dimensions of the final figure with a standard resol tion of $300 \mathrm{dpi}$ for photographs. Preferred formats are pdf tiff and jpg.

政e-The width of figures must be $82 \mathrm{~mm}, 125 \mathrm{~mm}$ or $171 \mathrm{~mm}$ Maximum height is $223 \mathrm{~mm}$.

Captions - Captions to figures, tables and plates must be delivered on separate pages.

Proofs

Proofs - Authors receive page proofs of the article after technical set-up. The cost of any alterations against the final mantscript will be charged to the author. 